\title{
Improving Quality of English Learning in Higher Education Through idREN
}

\author{
Husniyatus Salamah Zainiyati \\ Universitas Islam Negeri Sunan Ampel \\ Surabaya, Indonesia \\ Iconelt2019@gmail.com
}

\author{
Fahmy Imaniar \\ Universitas Islam Negeri Sunan Ampel \\ Surabaya, Indonesia \\ Iconelt2019@gmail.com
}

\begin{abstract}
In this digital era, information and technology come into almost every single aspect of education in various levels including higher education in which researchbased activities are carried out. Indonesian government responded to the aforementioned condition by having idREN (Indonesia Research and Education Network) as a platform for highereducation practitioners to share research and learning materials one another, to have collaborative research, as well as to develop research-based activities for various disciplines. Since idREN is multidisciplinary, it is highly possible and beneficial to use it in order to improve the quality of English learning in higher education. It is important to realize that English is an important subject, the competency of which higher-education students need to have. Therefore, this conceptual paper will describe domains dealing with how idREN can improve the quality of English learning in higher education context as a response and utilization of the platform that Ministry of Research, Technology, and Higher Education has launched. The exploration will emphasize on aspects of English learning which idREN can be engaged, including learning methods, materials, assessment, and other aspects. Hence, it is expected that idREN can be optimally used in higher education institutions dealing with English learning for its quality improvement and also sustainable development.
\end{abstract}

Keywords: idREN, Technology

\section{INTRODUCTION}

Everyone now is living in an era of modern world in which information, communication, and technology are always developing and getting more and more advanced as the time goes by. The advancement certainly gives impacts towards every single aspect of human life, including their life style, environment, and also their education. Verene (2013) explains that technology does not look back, but promises a better future, because everything that we want to do can be done better with technology. Unfortunately, the advancement may also emerge negative effects towards human or the people living in this era who are unable to use and utilize the technology as it should be. Therefore, educators, including teachers and lecturers, are demanded to be creative in using and utilizing the technology-based media that have already existed or even developed the media in order to achieve the effective learning goals (Zainiyati, 2017).

Learning is an essential element in life since it determines the success of an educational institution. A good learning has to be well-planned in order to achieve the goals that have been set previously. Through a systematic and efficient learning, the graduates, as the outcomes, will surely be better in terms of the quality. Similar thing happens to learning in higher education context which cannot be separated from the role of technology as well as internet and electronic stuffs. Moreover, technology ease teachers and students to deal with the activities they have in the teaching and learning process. Technological development is therefore becomes as the most important factor in initiating and expanding distance, including online and blended learning, win which the educational technologies is the one which facilitate the process (Cloete, 2017).

Young generation in this revolution industry 4.0 era are mostly digital natives which means that they are engaged into sophisticated technology already. In this case, educators need to be able to follow the advancement of era as well as its technology in order to build good rapport with the students and connect to their world. Therefore, it is expected that the learning process will run actively and effectively in accordance with the students' competence and interests.

Most technology requires good internet connection, therefore, such element in higher education institutions becomes a necessary element to concern, including for universities. In practical field, there are a number of universities in Indonesia which have troubles with weak internet connection. Such condition leads to ineffective learning when they actually should have no problem with this issue for utilizing any technological matters. Moreover, if technology is used appropriately, it can lead to a number of advantages to both teachers and students (Ahmadi, 2018).

In order to connect one university and other universities, REN exists as a platform which enables such connection as well as sharing of various things held in universities. In Indonesia, REN comes to provide advantages and ease for improving the quality of learning in higher education institutions all over Indonesia. Because of the need of engagement to the information, communication, and technology in this era, idREN is considered as a suitable platform to accommodate those need. many industries have realized that their own success and survival in a globally competitive arena depends greatly on their ability to implement new, relevant technologies to stay ahead of their competition, not only nationally, but also at the global level (Fahmy, 2004). Education can do the same.

Utilizing technology in learning prevails for various subjects including English since it is a subject that exists in any higher education institutions. Students, although they 
come from different majors, need English as a skill not only for their study, but also for their future career. In higher education level, the requirement of students to master English follows the National Education Law (Depdiknas, 2001c, cited in Emilia, 2005). Many universities also asks their students to have good English proficiency. Moreover, in Indonesia, the need of English proficiency for college students today is compulsory as they have to take English proficiency test for some important purposes. Not only for the universities with English department, other higher education institutions which have no English department still provide English learning as compulsory general courses for their students to take since English proficiency is considered very important. Moreover, nowadays students from various majors need to take TOEFL/TOEIC test, reach some standardized score, and get the English proficiency (TOEFL/TOEIC) certificate as part of graduation requirements. Some of them even need to have it before taking the final thesis examination. Therefore, English learning in higher education need to be concerned and improved.

To improve the quality English learning in universities, adjustment to the development of technology becomes a way that education practitioners can call into service. Richards (2015) states that there are two essential dimensions for successful language learning, esepcially second language learning, including the things inside the classroom and the things happen outside of the classroom. Technology can be engaged and utilized in English learning in order to improve its quality as well as to result an effective learning. It was supported by Eady \& Lockyer (2013) that technology now is a part that cannot be separated from learning experience and moreover considered as a significant issue for teachers dealing with the teaching and learning process.

IdREN platform can be enganged in English learning in order to reach the aforementioned aims. Through idREN, educational practitioners in higher education institutions are able to access, share, and make the best use of technology to improve the learning so that the learning will be much more effective and suitable for young generation in this era. Therefore, this paper will describe idREN and how it can be used for improving the quality of English learning in higher education.

\section{A. Indonesia Research Education Network (idREN).}

In this era of revolution industry 4.0 , a computer is not only a computer. It has been adopted, adapted, and replicated in terms of its application in various matters and various forms. A number of aspects in life cannot be separated form the ongoing advancement of technology, including social aspects. Furthermore, there is an assumption that technological products have controlled human's life. The important thing for this situation is that the society needs to be aware of the three kinds of literacies including data literacy, technology literacy, and also human literacy, as the addition to reading, writing, and counting as the former literacy skills that have already been existed. Data literacy, technology literacy, and also human literacy exist also in education in which they are really applied and needed.

IdREN is a network that accommodate the aforementioned three kinds of literacy in a networking connection among universities all over Indonesia in terms of research-based matters. Historically, this kind of platform was firstly established in Europe providing interconnection for research institutions in education in 2002. At that time, it was called Edurom which internationally used for researchbased matters in higher education context. In Indonesia, there are two universities using Edurom, ITB and also UII. This kind of platform is now called idREN or Indonesia Research Education Network (Budi, 2017:1)

So far, there are 5 higher education institutions connected to idREN. They are ITB, UI, ITS, UB, UGM) as the AdHoc team, cooperated with Telkom as the founder. Telkom supports the basis of the idREN network which is similar to TEIN (Trans Eurasia Information Network) supporting REN. There are also some other universities having used idREN but they are not the AdHoc team since the implementation of idREN is still being tried out due to several problems.

The most problematic issue of utilizing technology is about the internet connection. The more the users, the slower it is. In Thailand, every university connected through REN has big bandwidth around 1-10 Gbps. Unfortunately, in Indonesia, reaching badwidth $1 \mathrm{Gbps}$ is a big deal. Mostly, universities in Indonesia run the connection with small bandwidth of 1 or $2 \mathrm{Mbps}$ and the network used is ordinary internet connection, not REN (Ismunandar, 2019:2). However, if higher education and academe are to improve the rate of change that technological applications bring, they need to find new ways to fund such efforts (Fahmy, 2004).

Despite the insufficient bandwidth that Indonesian universities have, it is important to start thing about starting idREN in universities since the cost goes together with the advantages. By having big badwidth, long-distance communication can be done without troubles which also lead to better online classes with better visual and audio. It is possible also for universities to connect and develops themselves through idREN. In idREN provides various applications for research and learning development for higher education. A lot opportunities included in idREN enables various opportunities for sharing, cooperation, collaboration; not only at national level but also at international one. Such opportunities are mostly needed by universities in improving the quality of the university including all the learning as well as the students and the lecturers.

\section{B. Factors in Improving Learning Quality in Higher Education through idREN.}

If idREN is going to be used as a mean of improving learning quality, especially in higher education, there are some factors that need to acommodate including the vision and mission of the institution, the management of organization, the rules or ethical codes, the quality of human resources, the infrastructure, the cooperation with other parties, and also the adjustment to the advanced period but at the same time still maintaining the special character or the national character.

\section{Vision and mission}

The use of idREN needs to adjust the vision and mission of the institution. If the mission and vision of the 
institution cover the element of technological matters, then idREN will be a good networking platform to bring the vision and mission into reality.

\section{Management of organization}

In order to run idREN, there should be people with some roles for organizing its run, its complementaries, as well as its continutity. Moreover, applying such big networking platform in a university is not simple. Therefore, a systematic organization is neede in order to manage those things.

\section{Rules or ethical codes}

In having connection between institutions, there are rules and ethical codes that needs to be obeyed. Similar to research, idREN there are also rules and ethical codes in order to manage the universities which stay or become its members. Moreover, idREN is based on research, that is why the ethical codes of research are also accounted.

\section{Quality of human resources}

The quality of human resources is an important factor that will affect the run of idREN. Since it is a technology-based networking platform with big bandwidth, experts and also good technicians. Without qualified human resources, it is difficult to run idREN as it is.

\section{Infrastructure}

Infrastructure is the most essential part if an institution is going to implement idREN since it deals with all the components and basic foundation. Without good insfrastructure, idREN cannot be implemented and cannot be used optimally.

\section{Cooperation with other parties}

A university cannot run idREN by itself. Instead, it should involve a lot of parties starting the educational parties until the ones which supply the components and rquirements of implementing idREN. The network supply such as Telkom, for example, is one party which a university or any higher education institution needs to cooperate with because without the adequate networking connection, there will be no idREN run.

\section{Adjusting to the advanced period but still maintaining the character}

Despite the sophisticated technology used by idREN, the institution needs also to maintain the national character as Indonesian. Through connection with others and the whole world is getting easier, and idREN supports it, this factor becomes essential to preserve the culture, the character, and the nationalism when using idREN.

\section{Way to Start Accessing idREN.}

In order to start utilizing idREN, a university is required to have a good bandwidth and register to idREN. There are a number of preparations that a university needs to deal with, such as hardware, good connections, until technicians who can help with troubles that may come during the utilization of idREN.
When the preparations are all done, then network peering configuration should be done to connect to the main network. All the systems are synchronized in this step while also collecting the data of the education practitioners and other people who are going to be the users of idREN. After everything has been settled, there will be account of password for the users. Similar to other online platform, the users need to input the account ID and also the password so that they can enter idREN and get various advantages it has for improving the quality of education and also learning which relates to research.

Lecturers who involved their students in the utilization of idREN later need to provide preliminary guidance. The online-based learning that will be run needs configuration, introduction, and customozation. Therefore, it is important for them to make sure that the ones entering idREN network and do activities there will have active and interactive discussion for the better learning situation and result (Zainiyati, 2017)

\section{Improving Quality of English Learning Through idREN.}

IdREN contributes to the development of learning in all subjects including English which is learned by almost all students in universities in Indonesia, both English department and non-English department students. Learning does not only mean the condition of the existence of teacher and students in which the teacher delivers all the materials and the students have to take notes from what the teacher's explanation. Learning is more than that. A good and effective learning should activate students' capability as well as the teacher's in accordance to the advancement of the information, communication, and technology. The utilization of idREN for improving the quality of English learning can be done in several aspects including research sharing, learning material,learning media, learning method, learning assessment, collaborative works, and also academic events.

\section{Research sharing}

In terms of English learning, there are several aspects in which idREN can be utilized. First of all, since idREN is run on basis of research, sharing research between practitioners is one aspect that is very beneficial. Higher education cannot be separated from research. Educators as well as education practitioners continuously do research, the result of which can be shared to other ecuation practitioners in different universities all over Indonesia connected through idREN.

\section{Learning material}

In the practical field, the use of idREN is not always about the concrete research. Through idREN, practitioners and researchers are also able to share learning materials for various topics in English learning. The users also can access the learning materials developed by others.

\section{Learning media}

The number of studies done using research and development research design is high. Among them, the ones 
dealing with English are a lot. The effective learning media developed by one practitioner might be beneficial for others. This knowledge and media sharing can be done through idREN

\section{Learning method}

IdREN not only provides the most up-to-date knowledge of learning methods. It also bring uptodate knowledge of the newest method as well as the techniques and approaches dealing with English language learning. Users may share the classroom action research report that is successful in tehir classrooms or even adopt and adapt the methods which considered possible or beneficial to be implemented in their classroom.

\section{Learning assessment}

The same thing as learning media and also learning materials, idREN can also be used for sharing and donwloading learning assesment developed by practitioners.

\section{Collaborative works}

IdREN connects people and universities which leads to possibility of doing collaborative works. Mostly, the collaborative works deal with research. However, it does not mean that it cannot be done in other things including. Therefore, it is just not about sharing and taking from others.

\section{Academic events}

With the advatages of idREN, there are events that can be prepared, developed, and conducted by the university practitioners including the lecturers. The events usually need audiences from various settings, therefore idREN can really contributes to this point. The events can be in the form of workshop, seminars, and also conferences which might be done accross institutions adn involve a big scope.

\section{CONCLUSION}

Technology should be engaged into education and learning in order to adjust to the 4.0 era. Moreover, such adjustment deals also with the students as young generation who are already digital natives. In higher education, technology is not just a concept but it is a mean of achieving the education goals including effective learning as well as research development.

To accommodate the aforementioned condition, idREN serves as a networking platform that can be used to improve the quality of English learning in higher education context with emphasizing on several aspects with research as the basis. Although universities need to consider a lot of things including the cost of the big bandwidth in order to use idREN, it will surely give a plenty of advantages that can be utilized in any kinds of subject including English as the subject needed by students for not only their study but also their future career. IdREN can be applied in several aspects of English learning such as research sharing, learning material, learning media, learning method, learning assessment, collaborative works or even events, which are all relates to research. Through the utilization of idREN in those aspects, the quality of English learning will be improved. Therefore, it is also suggested that IDREN can be optimally used in higher education institutions dealing with English learning for its quality improvement and also sustainable development.

\section{REFERENCES}

[1] Ahmadi, M. R. (2018). The Use of Technology in English Language Learningg: A Literature Review. International Journal of Research in English Education, 3(2), 115-125

[2] Abdulmajid, N. W. A., Pramuntadi, A., Riyanto A. B., Rochmah, E. (2017). Penerapan E-Learning Sebagai Pendukung Adaptive Learning dan Peningkatan Kompetensi Siswa SMK di Kabupaten Bantul. Jurnal Taman Vokasi, 5(2), 170-182

[3] Cloete, A. L. (2017). Technology and education: Challenges and opportunities. HTS Teologiese Studies/Theological Studies, 73(4), 17

[4] Eady, M. J., \& Lockyer, L. (2013). Tools for learning: technology and teaching strategies: Learning to teach in the primary school. Queensland University of Technology, Australia. pp. 71-89. https://scholars.uow.edu.au/display/publication76376

[5] Emilia, Emi. (2005). A Critical Genre-Based Tertiary EFL Context in Indonesia. Ph.D. Thesis: The University of Melbourne.

[6] Fahmy, M. F. -. Thinking about Technology Effects on Higher Education. The Journal of Technology Studies, Pi Chapter of Epsilon Pi Tau.

[7] Imaniar, F., Lestari, A. L., Munir, A. (2018). The Teaching and Learning of Academic Writing Involving Critical Thinking in Higher

Education. Journal of English Language and Literature, 10(1), 975981

[8] Ismunandar. (2019). Rencana Pengembangan dan Inovasi

Pembelajaran Daring. Ministry Of Research, Technology, and Higher Education

[9] Richards, J. (2015). The changing face of language learning: Learning

Beyond the Classroom. RELC Journal, 1-18

[10] Verene, D. P. (2013). Does online education rest on a mistake?, Academic Quest, 26, 296-307.

[11] Zainiyati, H. S. (2017). Pengembangan Media Pembelajaran Berbasis ICT. Jakarta: Kencana

[12] Zainiyati, H. S. (2017). Students Participation and Perception in Threaded Online Discussion. Jurnal Advances in Sosial Science, Education and Humanities Research: Volume 145

[13] Zainiyati, H. S. (2017). Understanding The Cognition Process of The Students Using The Internet As a Learning Resource. Jurnal Pendidikan Islam: Volume 3 (1) 57-68 